\title{
EFEKTIFITAS DAN EFISIENSI PENERAPAN E-COMMERCE PADA PT. WAHANA SURYA PLASTIK
}

\author{
*(Sabilar Rosyad \\ Prodi Manajemen, Fakultas Ekonomi, Universitas Islam Lamongan \\ $\mathrm{Jl}$. Veteran No.53A Lamongan \\ Telp. ( 0322 ) 324706, Faks. ( 0322 ) 324706 \\ Email :jpim.unisla@gmail.com
}

\begin{abstract}
ABSTRAK
Globalisasi serta tingginya intensitas persaingan bisnis menuntut perusahaan untuk bisa memperhatikan dan memenuhi dinamika kebutuhan pelanggan dengan cara yang efektifdanEfisien dengan mengimplementasikan teknologi dalam perusahaan. Salah satunya dengan menerapkan e-commerce. Dalam penelitian ini akan dikaji mengenai tantangan atau kendala serta manfaat yang dirasakan perusahaan dalam mengimplementasikan e-commerce sebagai media pemasaran. Serta dikaji sejauh mana efektifitasdanEfisiensi penerapan ecommerce dalam perusahaan.

Penelitian yang digunakan oleh penulis ini adalah penelitian deskriptif kualitatif. Berdasarkan analisis yang ada diperoleh beberapa kendala atau tantangan dalam menerapkan e-commerce di PT. Wahana surya plastik, Pada pelaksanaannya e-commerce membutuhkan tenaga kerja (SDM) yang cukup ahli dalam bidang teknologi informasi yang menguasai e-commerce dengan berbagai perangkat serta persoalannya. Selain itu dalam menerapkan e-commerce juga dibutuhkan infrastruktur berkualitas yang membutuhkan modal cukup besar untuk mendapatkannya. Perusahaan harus menyesuaikan dengan adanya e-commece,dengan cara memaksimalkan SDM yang ada. Melalui e-commerce perusahaan dapat memperluas market place,mendatangkan pelanggan baru, dapat memberikan pelayanantanpa batas waktu kepada konsumennya, akses informasi yangcepat, serta dapat melakukan pendekatan hubungan yang baik kepada pelanggan. E-commerce masih kurang efektifdanEfisien diterapkan pada PT. Wahana Surya Plastik, oleh karena itu diharapkan setelah memaksimalkan SDM yang ada efektifitasdanEfisiensi penjualan harus semakin meningkat sebagai tujuan akhir perusahaan.
\end{abstract}

Kata Kunci: Efektifitas, Efisiensi, Penerapan

\section{PENDAHULUAN}

Perkembangan internet menyebabkan terbentuknya sebuah dunia baru yang lazim disebut dunia maya. Di dunia maya ini setiap individu memiliki hak dan kemampuan untuk berintraksi dengan individu lain tanpa batasan apapun yang dapat menghalanginya. Globalisasi yang sempurna sebenarnya telah berjalan di dunia maya menghubungkan seluruh komunitas digital. Dari seluruh aspek kehidupan manusia yang terkena dampak Jurnal Penelitian Ilmu Manajemen kehadiran internet, sektor bisnis merupakan sektor yang paling merasakannya. Pertumbuhan bisnis semakin cepat . Melalui E-commerce, untuk pertama kalinya seluruh manusia di muka bumi memiliki kesempatan dan peluang yang sama agar dapat bersaing dan berhasil bersaing di dunia maya.

Internet adalah sistem informasi global berbasis komputer. Bergaul dengan internet sama juga bergaul dengan komputer. Internet tidak akan pernah ada 
tanpa komputer. Ibarat kapal tanpa nahkoda, pastinya tidak mampu berjalan. Begitu juga dengan internet; tanpa adanya komputer kita tidak bisa mengakses internet. Untuk mengakses internet kita hanya membutuhkan seperangkat komputer, modem, dan saluran telpon. Bahkan saat ini tidak perlu mempergunakan jaringan telpon, cukup dengan menggunakan wireless internet.

Adapun fasilitas dalam internet yaitu E-mail (surat elektronik), Bulletin Board System (BBS), File Transfer Protocol (FTP), Information Browsing (gopher), Remote Login (Telnet), Advanced Browsing (www), Automated Title Search, Komunikasi audio dan visual.

Banyak perusahaan dan organisasi kini telah menerapkan teknologi berbasis internet, dunia web, dan sistem komunikasi nirkabel/wireless untuk mengubah bisnis mereka selama lebih dari 15 tahun sejak penciptaan situs web pertama (http://info.cern.ch) oleh Sir Tim BernersLee pada tahun 1991.

E-Business dan E-Commerce adalah area yang menarik untuk dikembangkan dan dipelajari karena banyak peluang dan tantangan baru muncul setiap tahun, bulan, dan bahkan setiap hari. Inovasi akan terus berkembang dengan adanya penemuan teknologi baru, model bisnis baru, dan pendekatan komunikasi baru. Sebagai contoh, Google berinovasi tanpa henti. Layanan telah berkembang jauh sejak tahun 1998. Miliaran halaman sekarang diindeks. Layanan lainnya seperti web mail, pay per click adverts (per klik iklan berbayar), analisis, dan social network (jaringan sosial), merupakan bagian dari penawaran.

Pertumbuhan e-commerce nampaknya akan berkembang terus seiring dengan makin memasyarakatnya jaringan global internet, bahkan beberapa pakar teknologi informasi memprediksi bahwa internet akan menjadi bagian sehari-hari masyarakat modern pada masa mendatang.
Ini artinya mereka akan demikian kental berurusan dengan internet dalam segala hal termasuk membeli atau menjual barang dan jasa. Begitu pula perusahaanperusahaan akan mengupayakan pelebaran pangsa pasarnya melalui jaringan internet sebagai strategi baru yang sangat global. Dengan kata lain e-commerce akan menjelma menjadi infrastruktur bisnis alternatif yang mumpuni pada era informasi kini dan mendatang (lkhtfhui.net).

E-commerce adalah lahan baru untuk membangkitkan dan mengeksploitasi bisnis yang mengutamakan efektifitas dalam pelaksanaannya. E-commerce menyelenggarakan transaksi bisnis melalui jaringan elektronik dengan sejumlah perbaikan terhadap kinerja bisnis tradisional. Sehingga akan tercipta wajah bisnis baru dengan unjuk kerja lebih baik: kualitas interaksi, kepuasan pelanggan dan efektifitas pembuatan keputusan.

Salah satu perusahaan yang telah sukses dengan menerapkan e-commerce adalah Amazon.com di Amerika, yang telah berhasil menjual buku dengan omzet jutaan dolar tanpa perlu memiliki gudang untuk menyimpan buku, membuka toko buku, apalagi menerbitkan buku (www.itcentre-komunitas teknologi informasi indonesia), Kemudian kesuksesan juga diraih Matahati Putra Prima tbk dengan menerapkan ecommerce. Perombakan struktur bisnis dan manajemen juga dilakukan Lippo untuk memperbaiki kinerja usaha PT. Matahari Putra Prima tbk. Lewat implementasi ecommerce B2B, dan meningkatkan kinerja implementasi sistem e-commerce B2B (Business to Business) yang sudah go live sejak tahun 1999 lalu. Saat ini matahari tercatat sudah berhubungan secara elektronis dengan pemasok besarnya seperti Martha Tilaar, Mustika Ratu, dan Nestle.

Saat ini, dengan bergabung kepada gateway indosat.com, para pemasok 
matahari bisa memangkas biaya administrasi pengadaan barang sebesar $50 \%$. Angka ini berasal dari berkurangnya biaya pengiriman faks, pengarsipan, dan entry data. Jelasnya kalau sebelumnya biaya pengurusan per dokumen mencapai Rp. 5964, maka sesudah ecommerce B2B diterapkan, ongkosnya hanya Rp. 2854 per dokumen (www.wartaekonomi.com).

Kemudian dalam sebuah penelitian yang dilakukan di 27 perusahaan di Indonesia yang telah menerapkan ecommerce dengan meneliti motif dan manfaat yang dirasakan perusahaan dikatakan bahwa motif yang melandasi perusahaan terdorong menggunakan ecommerce yaitu Mengakses Pasar global sebesar 56\%, Mempromosikan produk sebesar 63\%, Membangun Merk sebesar $56 \%$, Mendekatkan dengan pelanggan sebesar 74\%, Membantu komunikasi lebih cepat dengan pelanggan sebesar $63 \%$ dan Memuaskan pelanggan sebesar $56 \%$ kemudian dari 27 perusahaan yang telah menerapkan e-commerce bahwasannya $30 \%$ diantaranya merasakan manfaat meningkatnya omzet penjualan. $25 \%$ merasakan manfaat peningkatan jumlah pelanggan, $16 \%$ perluasan jangkauan bisnis dan sarana promosi, 5\% mendapatkan peluang terbukanya bisnis baru dan kepuasan pelanggan, serta $2 \%$ merasakan kemudahan hubungan relasi (www.spica almalia.wordpres).

Kenyataan ini membuktikan bahwa e-commerce memiliki peran penting dalam membantu meningkatkan omzet penjualan, efisiensi pada tenaga kerja dan seluruh biaya operasional yang perlu dikeluarkan untuk pembuatan produk dan pemasarannya. Makin ketatnya persaingan, mengharuskan dunia usaha Indonesia secara terus menerus melakukan efisiensi, meningkatkan kualitas produk, pelayanan serta inovasi baru. Efisiensi dilakukan secara total mulai dari perencanaan, proses produksi, pemasaran dan pendistribusian dengan menggunakan internet bisa mengurangi biaya staf infrastruktur dan biaya lainnya yang biasanya harus dibayar oleh perusahaan tradisional. Bila perusahaan di Indonesia tidak mengubah cara bisnisnya maka sulit untuk bisa bersaing dengan perusahaan lain yang mampu menawarkan barang dan jasa yang sama dengan harga yang lebih murah.

Telah dikatakan bahwa berbisnis di internet telah berpengaruh besar dalam berbagai jenis bisnis. Begitu juga dengan real esatate dan industri perjalanan (travel) berkembang secara dramatis dengan semakin banyaknya konsumen yang berbelanja melalui internet, karena kemudahan serta keuntungan besar yang ditawarkan cara bisnis baru ini, banyak perusahaan yang membawa bisnisnya kearah online.

Melihat kenyataan persaingan bisnis yang ketat, maka penerapan teknologi ecommerce merupakan salah satu faktor yang penting untuk menunjang keberhasilan suatu produk dari sebuah perusahaan. Untuk mempercepat dan meningkatkan penjualan cepat maka dengan melihat perubahan teknologi informasi yang sangat pesat tersebut kita dapat memanfaatkan suatu layanan secara online yang berupa ecommerce. Karena itu dalam penelitian ini akan dikaji tentang manfaat yang dirasakan oleh perusahaan yang telah menerapkan e-commerce dalam kepentingan bisnis serta tantangan yang dihadapi perusahaan dalam menerapkan ecommerce. penelitian ini diharapkan dapat diperoleh gambaran yang jelas tentang manfaat yang dirasakan PT. Wahana Surya Plastik dengan menggunakan e-commerce serta tantanganya. Temuan ini sangat penting terutama dalam memberikan informasi yang lebih jelas tentang dasar pertimbangan dalam menggunakan ecommerce dan memanfaatkannya sebagai sarana keunggulan bersaing.

\section{METODE PENELITIAN}


Berdasarkan jenisnya penelitian ini merupakan penelitian kualitatif, Jika penelitian kuantitatif pengumpulan data yang banyak di gunakan untuk pengambilan kesimpulan yang mantap, penelitian kualitatif menggunakan berbagai prosedur pengumpulan data dalam rangka menegaskan berbagai prosedur pengumpulan data dalam rangka menegaskan wawasan yang sedang di kembangkan dan menjamin kepercayaan data yang di kumpulkan (Suharsimi Arikunto, 2010:25).

Empat dasar filosofis yang berpengaruh dalam penelitian kualitatif yaitu sebagai berikut:

1. Fenomenologis, yang berpendapat bahwa kebenaran sesuatu itu dapat di peroleh dengan cara menangkap fenomena atau gejala yang memancar dari objek yang di teliti.

2. Interaksi simbolik, yang merupakan dasar kajian social yang sangat berpengaruh dan di gunakan dalam penelitian kualitatif.

3. Kebudayaan sebagai sesuatu yang merupakan hasil budi daya manusia mewujud dalam tingkah laku atau benda, bahasa, symbol, dan lain lain.

4. Antropologi yaitu dasar filosofis yang focus pembahasannya berkaitanerat dengan kegiatan manusia, baik secara normative maupun historis.

Dalam penelitian ini, peneliti menggunakan penelitian deskriptif dengan penelitian studi kasus. Dalam penelitian studi kasus peneliti mencoba untuk mencermati individu atau sebuah unit secara mendalam. Peneliti mencoba menemukan semua variabel penting yang melatar belakangi timbulnya serta perkembangan variabel tersebut yaitu mengenai kekuatan perusahaan, kelemahan perusahaan, peluang yang ada, dan ancaman yang ada di lingkungan perusahaan.

Setelah data diperoleh dari studi pustaka dan riset lapangan dikumpulkan dan diklasifikasikan, maka langkah selanjutnya dalam penelitian ini adalah melakukan analisis data. Analisis data adalah suatu cara atau langkah untuk mengolah data primer maupun data skunder yang bermanfaat bagi penelitian guna mencapai tujuan akhir penelitian.

Anonymous (2009). Dalam metode kualitatif, instrumen pengumpulan data yang digunakan antara lain wawancara mendalam dengan individu, wawancara terstruktur dan nonstruktur, kelompok fokus, narasi, analisis konten atau dokumenter, observasi partisipan, dan penelitian arsip.

Penelitian ini berproses mulai dari tahap penyediaan data, reduksi atau seleksi data, display atau penyajian data, dan pengambilan kesimpulan data. Dan proses diatas tidak berjalan secara linear, tapi bersifat simultan atau siklus yang interaktif. karena itu dalam penelitian kualitatif, seorang peneliti idealnya harus melalui tahapan sebagai berikut:

1. Pengumpulan data, data yang ada dicari dan dikumpulkan semua. Pada tahap ini, peneliti juga bisa memulai proses klasifikasi awal (secara umum). Pada proses ini idealnya seorang peneliti juga melakukan pelacakan, pencatatan, pengorganisasian data yang relevan untuk memfokuskan pada masalah yang diteliti.

2. Tahap reduksi data, yaitu seleksi data, pemfokusan dan penyerderhanaan data, dari semua data yang sudah didapat. Setelah itu data yang tidak diperluakan disisihkan dan data-data yang penting untuk penelitian dikumpulakan jadi satu, dan diklasifikasikan menjadi lebih spesifik.

3. Melaksanakan kegiatan display atan penyajian data. Yaitu data yang diperoleh tersebut bisa disajikan dalam bentuk matrik maupun tabel-tabel yang bisa mewakili karakter yang diperlukan. 
4. Membuat simpulan sementara dan menguji kembali dengan metode triangulasi, baik menggunakan triangulasi peneliti, teori, data, maupun metode.

Dan tahap terakhir, yaitu membuat pernyataan atau simpulan mengenai apa yang dimengertinya secara bulat tentang suatu masalah yang diteliti dalam bahasa kualitatif yang diskriptif dan bersifat interpretatif. Sugiyono (2006: 277).

\section{PEMBAHASAN}

\section{Tantangan PT. Wahana Surya Plastik dalam Menerapkan E- commerce}

Dikatakan oleh bapak Budi dan beberapa karyawan di bagian pemasaran bahwa tantangan/kendala dalam menerapkan e-commerce muncul terkait dengan masalah sumber daya manusia (SDM). Dalam penerapannya, ecommerce memerlukan tenaga ahli yang mengerti tentang infrastruktur dengan berbagai persoalannya, serta membutuhkan tenaga yang ahli dalam bidang teknologi untuk menerapkan ecommerce. Penempatan karyawan yang ahli dalam bidang teknologi untuk penerapan e-commerce memang sangat penting mengingat rumitnya kontrak dan mekanisme transaksi elektronik melalui e-commerce.

Menurut Julian Ding sebagaimana dikutip oleh Darus Badrulzaman menentukan bahwa: "A contract is a struck when two or more persons agree to a certain course of conduct". Maksudnya, kontrak adalah sebagai pertemuan dalam dua atau lebih pihak setuju melakukan tindakan tertentu, sehingga pada saat itulah kesepakatan tercapai. Berdasarkan pendapat diatas maka secara umum mekanisme transaksi elektronik dalam novieman.com dapat digambarkan yaitu : E-Customer dan e-merchant bertemu dalam dunia maya melalui server, yang disewa dari internet server provider. Transaksi e-commerce disertai term of use, dan sales term condition atau klausa standar, yaitu pada umumnya emerchant telah melakukan klausa kesepakatan pada website-nya sedangkan e-consumer jika berminat tinggal memilih tombol accept atau menerima.

Pada saat telah tercapai kesepakatan antara kedua belah pihak kemudian diikuti dengan proses pembayaran yang melibatkan dua bank perantara dari masing-masing pihak yaitu Acquiring Merchant Bank dan Issuing Customer Bank. Prosedurnya ecustomer memerintahkan kepada Issuing Customer Bank untuk dan atas nama e-customer melakukan sejumlah pembayaran atas harga barang/jasa kepada Accuiring Merchant Bank yang ditujukan kepada e-merchant. Setelah proses pembayaran selesai, kemudian diikuti dengan proses pemenuhan prestasi oleh pihak e-merchant berupa hak-hak dari e-customer.

Jadi dalam menerapkan ecommerce harus disiapkan tenagatenaga terampil dalam bidang teknologi informasi yang mengerti e-commerce dengan segala persoalannya, termasuk Internet, Web, Database, pengamanan sistem, masalah-masalah hukum yang terkait dan lain-lain. Karena rumitnya mekanisme transaksi elektronik melalui e-commerce, penempatan SDM yang salah akan berakibat buruk bagi pihak manajemen maupun bagi konsumen. Pihak PT. Wahana Surya Plastik harus melakukan training terhadap karyawan lama dan melakukan seleksi yang ketat terhadap penerimaan karyawan baru untuk mengatasi masalah tenaga kerja yang tidak mampu mengoperasikan internet.

Sebenarnya tidak hanya karyawan PT. Wahana Surya Plastik saja yang harus meningkatkan kemampuan dan 
keilmuannya dalam bidang teknologi. Kita sebagai seorang muslim juga dituntut untuk meningkatkan kemampuannya dalam ilmu pengetahuan dan teknologi. Serta dituntut untuk menempatkan ilmu pengetahuan dan teknologi pada posisi yang diperlukan dalam kehidupan. Dengan ilmu pengetahuan manusia juga akan terangkat derajat kehidupannya.

Kendala lain yang dihadapi PT. Wahana Surya Plastik dikatakan oleh bapak Budi yaitu masalah penyediaan infrastruktur untuk menerapkan ecommerce. dalam penerapannya, ecommerce membutuhkan sebuah software. Untuk menjalankan ecommerce memang diperlukan beberapa service atau infrastruktur yang mendukung pelaksanaan e-commerce. diantaranya, directory service, public key infrastructure, certification Authority. (corbis.com: mengenal ecommerce).

Directory service menyediakan informasi tentang pelaku bisnis dan end user. Ada beberapa standar yang digunakan untuk menyediakan Directory Service. Salah satu standar yang cukup popular adalah LDAP (Lightweight Directory Access Protocol) yang kemudian menimbulkan Open LDAP (www.openLDAP.org).

Kemudian infrastruktur kunci publik dibutuhkan untuk menjalankan ecommerce guna menjaga keamanan. Salah satu cara untuk meningkatkan keamanan adalah dengan menggunakan teknologi kriptografi yaitu antara lain dengan menggunakan enkripsi untuk mengacak data. Infrastruktur yang ketiga adalah Certification Authority yang merupakan sebuah body/entity yang memberikan dan mengelola sertifikat digital yang dibutuhkan dalam transaksi elektronik. Untuk memperoleh semua infrastruktur diatas dibutuhkan biaya pembelian dan perawatan yang besar. Maka dari itu modal yang besar perlu disiapkan oleh pihak PT. Wahana Surya Plastik agar tidak mengganggu kegiatan operasional perusahaan dalam menerapkan e-commerce.

Masalah lain yang muncul ketika diterapkan e-commerce yaitu masalah ruang pasar e-commerce. Dikatakan oleh bapak Budi bahwa konsumen PT. Wahana Surya Plastik yang memesan produk secara online di PT. Wahana Surya Plastik untuk saat ini memang masih mencapai ruang pasar yang terbatas.

E-commerce mampu menembus batasan geografi antar negara sehingga dunia sepertinya sangat sempit. PT. Wahana Surya Plastik dapat mempromosikan produk-produk ke seluruh dunia dalam waktu bersamaan, dalam waktu singkat, dan dengan biaya yang sangat hemat. Akan tetapi saat ini masalah pangsa pasar e-commerce di Indonesia memang menjadi kendala dalam menerapkan e-commerce di PT. Wahana Surya Plastik. Berdasarkan informasi dari salah satu data, jumlah user internet baru dalam jumlah ratusan ribu. Untuk potensial pasar e-commerce sebenarnya adalah pengguna internet seluruh dunia. Dan di PT. Wahana Surya Plastik penerapkan e-commerce untuk mencapai pasar internasional belum maksimal hasilnya.

E-dagang (e-commerce) ini tujuannya untuk membantu konsumen, siapapun, dimanapun juga supaya dapat berhemat waktu dan uang dengan pelayanan terbaiknya. Namun orang kebanyakan masih menganggap percepatan ini sebagai hal elite dan eksklusif. Hal tersebut berakar dari kebisaaan orang yang tidak bisa lepas dari budaya membeli dalam kurun waktu yang cukup lama. Maka jika akan mulai membudayakan e-commerce hendaknya diimbangi pula dengan penanaman pemahaman yang 
menyeluruh tentang e-commerce guna membentuk budaya yang baru.

E-commerce laiknya anomali air. Orang menganggapnya sebagai barang yang elit tapi pemanfaatnya cukup banyak dan diproyeksikan meningkat. Ketika hal ini masih dianggap sebagai hal yang elit, kita harus berupaya untuk mengintregasikan ide baru bahwa ini merupakan 'barang' yang layak dinikmati oleh banyak orang.

Yang paling penting dalam merubah budaya yaitu tidak dilakukan oleh satu pihak saja namun bersamasama, antara pelaku bisnis secara langsung, pemerintah dan masyarakat sendiri. Semuanya itu sangat penting untuk merubah budaya dan asumsi masyarakat mengenai e-commerce ini. Justru pada saat anggapan, prediksi orang masih seperti ini, para dotcomers, pemikir IT, dan Komputer maniak/Cyber maniak seharusnya bisa masuk dan memberikan konstribusi yang berarti untuk mempengaruhi perubahan yang kita harapkan bersama, dengan kata lain sebagai katalisnya.

Untuk pasar Indonesia sebenarnya konsumen tidak harus memiliki akses sendiri. Telah banyak kantor, kampus, dan sekolah-sekolah yang memiliki akses. Disini pemerintah memang perlu turun tangan untuk memberikan insentif untuk pengembangan e-commerce di Indonesia.

\section{Manfaat E-commerce bagi PT. Wahana Surya Plastik}

Dikatakan oleh bapak Budi bahwa penerapan e-commerce di PT. Wahana Surya Plastik dapat memperluas market place ke pasar nasional maupun internasional. Dengan e-commerce PT. Wahana Surya Plastik dapat memperkenalkan berbagai fasilitas dan produknya keseluruh penjuru dunia.

Melalui e-commerce sebuah perusahaan memang bisa memperluas market place ke pasar nasional maupun internasional. Sebelum era internet, batas-batas geografi menjadi penghalang suatu perusahaan yang ingin go-international. Sehingga hanya perusahaan atau individu dengan modal besar yang dapat memasarkan produknya. Saat ini dengan internet siapapun dapat memasarkan produknya secara internasional cukup dengan membuat situs web di internet tanpa batas waktu (24 jam) dan tentu saja pelanggan dari seluruh dunia dapat mengakses situs tersebut dan melakukan transaksi secara online Selain karena karakteristrik e-commerce yang memungkinkan perusahaan untuk memperluas market place, sistem yang ada di dalam e-commerce juga mendukung perusahaan untuk memperluas market place. Karena di dalam sistem e-commerce terdapat tiga sistem aplikasi diantaanya: Electronic Markets (EMs), electronic data interchange (EDI), serta internet commerce.

Electronic Market (EMs) merupakan sebuah sarana yang menggunakan teknologi informasi dan komunikasi untuk melakukan/menyajikan penawaran dalam sebuah segmen pasar sehingga pembeli dapat membandingkan berbagai macam harga yang ditawarkan. Dalam pengertian lain, EMs adalah sebuah sistem informasi antar organisasi yang menyediakan fasilitas-fasilitas bagi para penjual dan pembeli untuk bertukar informasi tentang harga dan produk yang ditawarkan. Keuntungan fasilitas EMs bagi pelanggan adalah terlihat lebih nyata dan efisien dalam waktu. Sedangkan bagi penjual yaitu dpat mendistribusikan informasi mengenai produk dan service yang ditawarkan dengan lebih cepat sehingga dapat menarik pelanggan lebih banyak. Jadi melalui EMs kegitan untuk memperluas market place ke pasar 
domestik maupun manca negara bisa dilakukan.

Sedangkan internet commerce adalah penggunaan internet yang berbasis teknologi informasi dan komunikasi untuk perdagangan. Kegiatan komersial ini seperti iklan dalam penjualan produk dan jasa. Transaksi yang dilakukan di internet antar lain pemesanan/pembelian barang dan jasa dengan transfer uang ke rekening penjual. Penggunaan internet dalam menerapkan e-commerce sebagai media pemasaran dan saluran terbukti mempunyai keuntungan antara lain untuk beberapa produk tertentu lebih sesuai ditawarkan melalui e-commerce. Jadi melalui internet commerce kegiatan untuk memperluas market place ke pasar domestik maupun manca negara dapat dilakukan pula.

Pemanfaatan internet di PT. Wahana Surya Plastik sangat membantu manajemen Pt. Wahana Surya Plastik. E-commerce dapat menjadi media promosi yang sangat efektif dan merupakan alat bantu pemasaran yang sangat cocok dalam dunia perusahaan, dengan melihat prospek pelanggan di seluruh Indonesia bahkan diseluruh dunia.

Bagi perusahaan terutama yang bergerak dalam bidang jasa termasuk jasa penjualan yang mempunyai ekspansi pasar yang cukup luas dan ingin meningkatkan mutu layanan pelanggan PT. Wahana Surya Plastik yang memuaskan, kehadiran PT. Wahana Surya Plastik pada dunia maya merupakan strategi yang sangat bagus.

E-commerce merupakan salah satu kemajuan teknologi dan merupakan hasil karya manusia. Allah memberikan akal kepada manusia agar manusia memikirkan segala sesuatu untuk kesejahteraan hidupnya. E-commerce telah memberikan kontribusi besar dalam sebuah bisnis. e-commerce telah mampu menembus batasan geografi sebuah Negara sehingga bisa memperluas market place hingga ke pasar internasional. Ini merupakan sebuah karya besar/penemuan besar manusia.

Dikatakan pula oleh bapak Budi bahwa dengan e-commerce PT. Wahana Surya Plastik juga memperoleh manfaat yaitu mudah untuk melakukan akses informasi mengenai pelanggan serta dapat melayani konsumen tanpa batas waktu. Melalui e-commerce pihak manajemen bisa melayani konsumen dalam waktu 24 jam dan. Disini pihak manajemen dapat memberikan kemudahan kepada pelanggan yang tidak bisa memesan produk PT. Wahana Surya Plastik secara manual karena waktu yang mendesak atau alasan lain. Dengan layanan ini berarti pihak manajemen bisa memberikan kebebasan sepuas-puasnya kepada konsumen dalam melakukan transaksi tanpa terikat oleh waktu. Selain itu konsumen yang ingin melakukan pemesanan produk tidak perlu repot-repot untuk datang ke PT. Wahana Surya Plastik . Tetapi pemesanannya bisa dilakukan lewat internet dimanapun berada. Dengan hadirnya e-commerce pihak manajemen juga dapat memperoleh berbagai informasi mengenai pelanggan dengan cepat karena adanya fasilitas-yang mendukung di dalam e-commerce.

Dikatakan oleh bapak Budi bahwa melalui e-commerce PT. Wahana Surya Plastik juga mendapatkan kemungkinan mendatangkan pelanggan baru baik pelanggan baru yang berasal dari pasar domestik maupun pasar luar negeri Karena jangkauan e-commerce yang sangat luas, dan dilihat dari karakteristiknya bahwa e-commerce merupakan transaksi tanpa batas, maka berbagai informasi PT. Wahana Surya Plastik dan produk yang ditawarkan PT. Wahana Surya Plastik bisa diakses 
dalam waktu 24 jam tanpa dipengaruhi batasan geografi. Masyarakat di seluruh penjuru dunia dimungkinkan dapat melakukan transaksi saat itu pula. Dengan demikian dapat mendatangkan pelanggan baru. Pelanggan tidak hanya dari masyarakat lokal akan tetapi masyarakat secara global. Dengan datangnya pelanggan baru maka akan menambah keuntungan dari PT. Wahana Surya Plastik.

Manfaat lain yang dirasakan PT. Wahana Surya Plastik dengan ecommerce dikatakan oleh bapak Budi dan beberapa karyawan di bagian pemasaran bahwa para pemasar PT. Wahana Surya Plastik dapat melakukan pemupukan hubungan terhadap pelanggan. Karena sistemnya satu lawan satu, dan interaktif, pemasaran online (e-commerce) merupakan alat yang bagus untuk pembangunan hubungan pelanggan. Hubungan ini membuat pelanggan dan perusahaannya lebih akrab. Perusahaan dapat berinteraksi dengan pelanggan dan belajar banyak dari mereka tentang kebutuhan dan keinginan pelanggan yang khusus, dan untuk membangun pusat data pelanggan. Sebaliknya pelanggan online dapat mengajukan pertanyaan dan umpan balik yang cepat. Berdasarkan interaksi yang berjalan ini, perusahaan dapat meningkatkan nilai kepuasan pelanggan melalui perbaikan produk dan jasa (Kotler: 262).

$$
\text { Bisnis apapun bentuknya, }
$$
membutuhkan penjualan agar tetap survive. Begitu juga dengan bisnis perusahaan. Perusahaan pasti dan akan selalu membutuhkan kehadiran tamu untuk tetap survive dalam bisnis. Di PT. Wahana Surya Plastik juga demikian. PT. Wahana Surya Plastik juga mengharapkan pelanggan yang akan datang kembali untuk kedua kalinya dan begitu seterusnya. Untuk itu sangat diharapkan proses bisnis yang menggunakan teknologi informasi dan komunikasi untuk mencapai perubahan dan pertumbuhan bagi perusahaan. Salah satunya dengan e-commerce. Jika melalui e-commerce pemupukan hubungan dengan pelanggan dapat dilakukan secara maksimal maka dapat diprediksikan bisa mendatangkan keuntungan jangka panjang.

Teknologi telah memberikan manfaat besar dalam kehidupan manusia. Salah satunya adalah lahirnya e-commerce yang mewarnai kehidupan bisnis di dunia. Disamping kontribusi yang diberikannya e-commerce juga meninggalkan berbagai persoalan yang serius dan perlu ditangani oleh kita semua. Untuk itu yang menjadi tugas kita sebagai seorang muslim adalah memikirkan solusi dari masalahmasalah itu dengan pikiran yang lebih luas. Islam mencela orang yang berfikir sempit. karena itu akan menggendorkan dan melemahkan manusia dan menjadikannya terisolir dari dunia kehidupan yang sangat komplek.

E-commerce di PT. Wahana Surya Plastik memang efektif dalam hal memberikan pelayanan yang cepat dan segera terhadap pelanggan. Yaitu pihak PT. Wahana Surya Plastik dapat memotong waktu transaksi yang biasanya lebih panjang dengan cara-cara tradisional. Akan tetapi dalam ukuran kinerja untuk e-commerce, perusahaan harus memikirkan kinerja e-commerce dalam empat dimensi yang secara kolektif mengkombinasi ukuran saluran tradisional dengan indikator-indikator kinerja e-commerce baru diantaranya; volume situs e-commerce, meraih pendapatan dan pelanggan e-commerce, biaya e-commerce, dan keuntungan ecommerce. (sumber: Oxford Associates dalam buku The Channel Adventage).

Meraih pelanggan dan pendapatan dapat dilihat dari keberhasilan situs dalam meraih pelanggan dan 
penjualannya. Biaya, dapat dilihat dari investasi dan biaya operasi yang berhubungandengan situs. Keuntungan, dapat dilihat dari hasil yang diukur dari tingkat pengembalian investasi dan kepuasan pelanggan.

Dilihat dari jumlah pengunjung yang memesan secara online pada PT. Wahana Surya Plastik masih jauh hasilnya dibandingkan dengan cara-cara manual. Ini berarti keberhasilan situs ecommerce dalam meraih pelanggan dan penjualannya masih belum maksimal. Kemudian dilihat dari biaya, untuk menerapkan e-commerce perlu disediakan infrastruktur yang membutuhkan modal besar guna mendapatkan infrastruktur/software yang terjaga kualitasnya serta SDM yang ahli dalam bidang teknologi informasi yang juga membutuhkan biaya yang besar pula. Dilihat dari keuntungan yaitu hasil yang diukur dari tingkat pengembalian investasi dan kepuasan pelanggan, Maka jika respon masyarakat dengan hadirnya ecommerce pada PT. Wahana Surya Plastik masih jauh hasilnya dibandingkan dengan cara-cara manual maka penerapan e-commerce belum bisa mendatangkan keuntungan yang lebih besar daripada cara-cara manual.

Kembali pada pengertian efektifitas menurut Kurniawan, yang kemudian dikatakan efektifitas kemampuan melaksanakan tugas, ini artinya ecommerce masih belum efektif diterapkan di PT. Wahana Surya Plastik. Semua tanggung jawab sebagai marketing departement telah dilakukan pihak manajemen pemasaran. Akan tetapi untuk e-commerce memang masih banyak kendala yang menyebabkan e-commerce masih belum efektif diterapkan di PT. Wahana Surya Plastik.

Menurut Handoko (2001) efisiensi adalah kemampuan untuk menyelesaikan suatu pekerjaan dengan benar. Ini merupakan perhitungan perbandingan antara keluaran (output) dan masukan (input). Suatu kerja organisasi dikatakan efisiensi apabila mencapai keluaran yang lebih tinggi berupa hasil, produktivitas, performance, dibanding masukanmasukan yang berupa tenaga kerja, bahan, uang, mesin dan waktu yang digunakan. Dengan kata lain, dengan meminimumkan biaya pengguna sumberdaya untuk mencapai keluaran yang telah ditentukan, atau sebaliknya disebut efisiensi apabila dapat memaksimumkan keluaran dengan jumlah masukan yang terbatas, sehinggawaktudanbiaya yang di gunakanuntuk e-commerce lebihsedikitdanefisiendaripadapemasara nsecara manual.

\section{KESIMPULAN DAN SARAN Kesimpulan}

Dari hasil penelitian dan pembahasan yang telah dijelaskan pada bab sebelumnya, maka temuan ini dapat disimpulkan sebagai berikut:

1. Pada pelaksanaannya e-commerce membutuhkan tenaga kerja(SDM) yang cukup ahli dalam bidang teknologi informasi yangmenguasai e-commerce dengan berbagai perangkat sertapersoalannya. Selain itu dalam menerapkan e-commerce jugadibutuhkan infrastruktur berkualitas yang membutuhkan modalcukup besar untuk mendapatkannya. Perusahaan harus menyesuaikan dengan adanya ecommece,dengan cara memaksimalkan SDM yang ada.

2. Melalui e-commerce perusahaan dapat memperluas market place, mendatangkan pelanggan baru, dapat memberikan pelayanantanpa batas waktu kepada konsumennya, akses 
informasi yangcepat, serta dapat melakukan pendekatan hubungan yang baik kepada pelanggan.

3. E-commerce masih kurang efektifdanefisien diterapkan pada PT. Wahana Surya Plastik, oleh karena itu diharapkan setelah memaksimalkan SDM yang ada.EfektifitasdanEfisiensi penjualan harus semakin meningkat sebagai tujuan akhir perusahaan.

\section{Saran}

Berdasarkan hasil temuan serta analisa pembahasan peneliti memiliki saran-saran sebagai berikut:

1. Pihak manajemen hendaknya menyiapkan tenaga-tenaga terampil dalam bidang IT guna memperlancar aplikasi ecommerce pada PT. Wahana Surya Plastik. Serta memberikan training kepada karyawan lama dan seleksi yang ketat pada karyawan baru.

2. Pihak manajemen hendaknya dapat membuat website penjualan tersendiri semenarik mungkin, cepat di loading, serta mempunyai proses penjualan dan pembayaran yang mudah sehingga memudahkan konsumen untuk akses.

3. Pihak manajemen PT. Wahana Surya Plastik hendaknya menyiapkan tenaga pemasaran yang mampu memikirkan ide untuk merubah budaya dan asumsi masyarakat mengenai e-commerce.

\section{DAFTAR PUSTAKA}

Candra Ahmadi dan Dadang Hermawan. 2013. E-Business \& ECommerce, Penerbit Andi, Yogyakarta.
Dwiridottjahjono, jojok. Bagaimana Membangun Kualitas Layanan

Online. Usahawan No.07 TH XXXV Juli 2006

Kartajaya, Syakir Sula. 2006. Syariah Marketing. Penerbit PT Mizan Pustaka, Bandung.

Kotler dan Keller.2009. Manajemen Pemasaran Jilid , Edisi 13. Penerbit Airlangga, Jakarta..

Rangkuti, Freddy, 2005.Analisis SWOT Teknik Membedah Kasus Bisnis

Reorientasi Konsep

Perencanaan Strategis untuk Menghadapi Abad 21.Cetakan Kedua belas, Penerbit PT.Gramedia Pustaka Utama, Jakarta.

Sugiono. 2006. Metode Penelitian Kuantitatif Kualitatif, Penerbit Alfabeta, Bandung.

Spica,Almalia Penerapan E-commerce Sebagai Upaya Meningkatkan Persaingan

Bisnis Perusahaan 2007-03-08 www.spicaalmalia.wordpress.com

Indrajit, 1998, Lima Langkah Sukses Bisnis E-commerce. www.apjii.oid/ekoindrajit/PDF\%

http://explorable.com/quantitative-andqualitative-research.

www.ozziomahasiswaonline.wordpress.co m/2011/08/06/Pengertian-Pemasaran/ 